\title{
Hubungan Rerata Kadar Feritin dalam Serum dengan Gejala Klinik Gangguan Pemusatan Perhatian dan Hiperaktivitas Berdasarkan Skala Penilaian Perilaku Anak Hiperaktif Indonesia [SPPAHI]
}

Citra Fitri Agustina, Martina Wiwie Setiawan Nasrun, Tjhin Wiguna, Ika Widyawati

Departemen Psikiatri fakultas kedokteran universitas Indonesia/RS Dr. Cipto Mangunkusumo, Jakarta

\begin{abstract}
Latar belakang. Gangguan Pemusatan Perhatian dan Hiperaktivitas (GPPH) merupakan gangguan psikiatrik paling banyak pada anak, dengan prevalensi $26,2 \%$ di Jakarta. Serum feritin, diduga, memengaruhi patofisiologi GPPH terkait dengan aktivitas dopaminergik.

Tujuan. Mengetahui hubungan kadar feritin dengan gejala klinis GPPH serta mengetahui adakah perbedaan kadar feritin pada anak GPPH dan bukan GPPH.

Metode. Desain penelitian potong lintang, membandingkan 47 anak GPPH dan 47 anak sehat sebagai kontrol yang berusia 7-12 tahun (usia rerata 9,09 $\pm 1,29$ ). Uji korelasi Spearman digunakan untuk mengetahui hubungan kadar feritin dengan gejala klinis GPPH. Pemeriksaan serum feritin menggunakan metode Electrochemiluminescent Immuno Assay (ECLIA). Diagnosis GPPH ditegakkan dengan MINI KID, sedangkan gejala klinis GPPH dinilai berdasarkan Skala Penilaian Perilaku Anak Hiperaktif Indonesia (SPPAHI).

Hasil. Tidak didapatkan hubungan bermakna antara kadar feritin dengan gejala klinis GPPH, koefisien korelasi 0,108 ( $\mathrm{p}>0,05)$. Rerata kadar feritin anak GPPH adalah 38,7 ng/mL (median), yang tidak berbeda bermakna dengan kontrol (median $28 \mathrm{ng} / \mathrm{mL}$ ).

Kesimpulan. Tidak terbukti adanya hubungan antara feritin dengan gejala klinis GPPH. Masih diperlukan studi lebih lanjut untuk melihat peran feritin melalui dopamin pada GPPH.
\end{abstract}

Sari Pediatri 2014;16(3):173-7

Kata kunci: gangguan pemusatan perhatian dan/ hiperaktivitas, feritin, dopamin

Alamat korespondensi:

Dr. dr. Tjhin Wiguna, SpKJ(K), Staf Pengajar Divisi Psikiatri Anak dan Remaja, Departemen Psikiatri FKUI/RSCM, Jalan Kimia 2/35, Jakarta 10430. Telp./Fax. (021) 310741, (021) 39899128. Dr. Citra Fitri Agustina. E-mail: c_fitri_a@yahoo.com

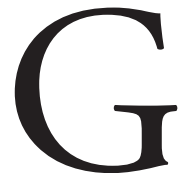
angguan Pemusatan Perhatian dan Hiperaktivitas (GPPH) telah menjadi perhatian besar bagi kalangan klinisi, ilmuwan, maupun masyarakat saat ini. ${ }^{1}$ Gangguan psikiatrik ini paling umum terjadi pada anak. Di 
Jakarta, prevalensi GPPH pada anak sekolah dasar adalah 26,2\%. Apabila dibandingkan dengan anak yang sehat, anak dengan GPPH mengalami kendala yang lebih besar pada fungsi psikososial dan fisik. ${ }^{3}$

Penyebab GPPH tidak diketahui pasti. Hingga saat ini, para peneliti meyakini bahwa gangguan ini disebabkan oleh berbagai faktor, seperti genetik, biologi, lingkungan, dan nutrisi. Berbagai studi menunjukkan peran dopamin sebagai salah satu elemen GPPH. Penelitian pada tikus dengan lesi pada tegmental ventral ditunjukkan perilaku hiperaktif dan masalah dalam fokus pada rangsangan tertentu. Defisiensi dopamin kortikal menyebabkan perilaku hiperaktif, masalah dalam penghambatan, orientasi spasial, dan organisasi temporal. ${ }^{2,4}$ Peran feritin juga telah dipelajari dalam kondisi yang berhubungan dengan GPPH. Kekurangan feritin memengaruhi kadar dopamin di substansia nigra dan putamen, serta/terhadap gangguan neurologis lainnya, termasuk terlambatnya perkembangan, stroke, pseudotumor serebri, dan kelumpuhan saraf kranial. ${ }^{4}$

Penelitian mengenai GPPH yang dilakukan di India, disimpulkan nilai rerata kadar feritin dalam serum jauh lebih rendah dibandingkan kontrol. Sebaliknya, penelitian lain menyatakan tidak ada perbedaan bermakna kadar feritin dalam serum anak GPPH dibandingkan anak sehat. ${ }^{5}$

Penelitian ini bertujuan mengetahui hubungan serum feritin dengan gejala klinis GPPH. Untuk mengetahui gejala klinis GPPH digunakan instrumen Skala Penilaian Perilaku Anak Hiperaktif Indonesia (SPPAHI). Diagnosis GPPH dilakukan dengan wawancara terstruktur menggunakan Mini International Neuropsychiatric Interview Kid (MINI KID). Penelitian ini juga bertujuan untuk mengetahui perbedaan rerata kadar feritin serum antara kelompok anak GPPH dan kelompok anak sehat sebagai kontrol.

\section{Metode}

Penelitian potong lintang ini dilaksanakan pada bulan April - Juni 2013 di SD Negeri 01 dan 02 Kampung Melayu. Orangtua telah mendapat penjelasan serta menyetujui anaknya ikut dalam penelitian dengan menandatangani lembar persetujuan (informed consent). Kriteria inklusi untuk kasus adalah anak SD usia 6-12 tahun dengan GPPH tanpa disertai gangguan jiwa lainnya, dalam keadaan sehat fisik, hasil laju endap darah normal, kecerdasan rata-rata dan di atas rata-rata, pendidikan orangtua minimal SMP. Kriteria inklusi untuk kontrol adalah anak SD usia 6-12 tahun, sehat fisik dan jiwa, hasil laju endap darah normal, kecerdasan minimal rata-rata.

Berdasarkan tingkat kepercayaan 95\% dan power test $80 \%$ diperoleh besar sampel 47 anak untuk masingmasing kelompok. Pemilihan kelompok kasus dilakukan dengan cara simple random sampling, sedangkan untuk kontrol dilakukan age and sex matched dengan kelompok kasus (stratified random sampling). Kadar feritin dalam serum diperiksa dengan metode Electrochemiluminescent Immuno Assay (ECLIA) yang dilakukan di laboratorium. Perbedaan kadar feritin dalam serum antara kedua kelompok dianalisis dengan uji t tidak berpasangan dengan nilai $\mathrm{p}<0,05$ menunjukkan perbedaan tidak bermakna. Untuk mengetahui hubungan kadar feritin dengan gejala klinis GPPH digunakan uji korelasi Spearman. Penghitungan statistik menggunakan program SPSS 16.0. Penelitian dimulai setelah mendapatkan persetujuan Komite Etik Penelitian Kesehatan Fakultas Kedokteran Universitas Indonesia/ RS. Cipto Mangunkusumo, Jakarta.

\section{Hasil}

Karakteristik subjek penelitian meliputi usia anak, jenis kelamin, dan total indeks massa tubuh (Tabel 1). Setiap kelompok terdiri atas 47 anak dengan rerata usia 9,09 tahun. Berdasarkan karakteristik pendidikan ayah, pendidikan setingkat SMU, dan sederajat menunjukkan angka tertinggi baik pada kelompok GPPH maupun anak sehat (pendidikan ayah 63,8\%; 78,7\%). Pendidikan Ibu yang paling

Tabel 1. Karakteristik subjek penelitian

\begin{tabular}{lcc}
\hline Karakteristik & $\begin{array}{c}\text { Anak GPPH } \\
(\mathrm{n}=7)\end{array}$ & $\begin{array}{c}\text { Anak sehat } \\
(\mathrm{n}=47)\end{array}$ \\
\hline Jenis kelamin & & \\
$\quad$ Laki-laki & $29(61,7)$ & $29(61,7)$ \\
$\quad$ Perempuan & $18(38,3)$ & $18(38,3)$ \\
Usia, tahun & & \\
$\quad$ Rerata (SD) & $9,09(1,299)$ & $9,09(1,299)$ \\
$\quad$ Kisaran & $7-12$ & $7-12$ \\
Indeks massa tubuh & & \\
Rerata (SD) & $15,88(3,78)$ & $15,87(3,32)$ \\
\hline
\end{tabular}


Tabel 2. Kadar Ferritin dalam serum pada kelompok GPPH dan anak sehat

\begin{tabular}{lccc}
\hline & Kelompok GPPH $(\mathrm{ng} / \mathrm{mL})$ & Kelompok Anak Sehat $(\mathrm{ng} / \mathrm{mL})$ & $\mathrm{p}$ \\
\hline Nilai tengah & 38,7 & 28 & $0,382^{*}$ \\
Kisaran & $7,10-174,0(166,90)$ & $6-111(105)$ & \\
\hline
\end{tabular}

*Mann-Whitney U-Test

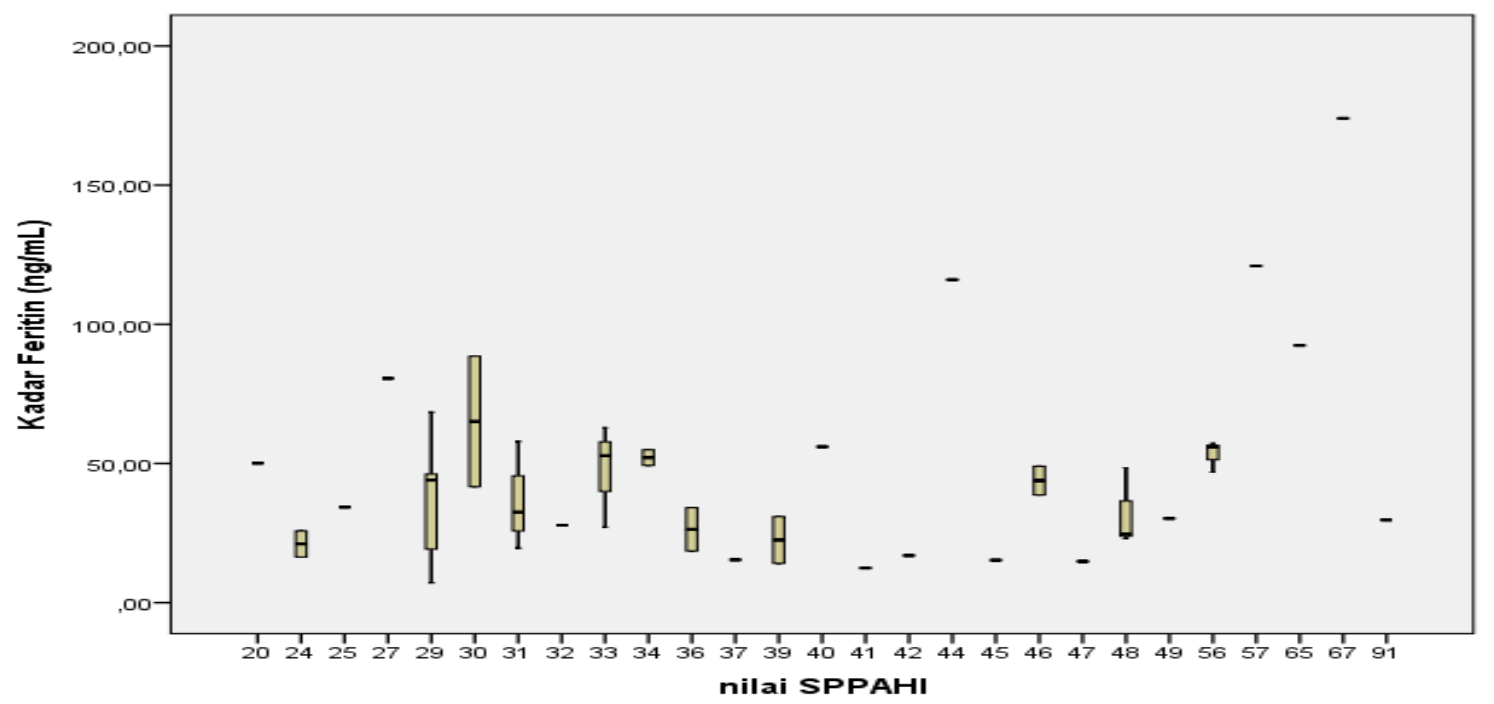

Gambar 1. Hubungan gejala klinik GPPH dengan kadar feritin

banyak dijumpai adalah lulusan SMU/sederajat dengan persentase $63,8 \%$ pada masing-masing kelompok. Berdasarkan karakteristik pekerjaan orangtua pencari nafkah pada kelompok GPPH, lebih banyak orangtua yang bekerja sebagai wiraswasta (42,55\%), sedangkan pada kelompok anak sehat lebih banyak orangtua yang menjalani profesi di sektor informal (34\%), sebagai buruh, juru parkir, dan pengemudi. Berdasarkan status pernikahan orangtua pada kedua kelompok, status menikah jauh lebih banyak dengan persentase $95,7 \%$ dan 93,6\%. Status ekonomi menengah ke bawah-85,1\% pada kelompok GPPH dan 80,9\% pada kelompok anak sehat-mendapatkan persentase paling tinggi pada kedua kelompok.

Kadar feritin dalam serum pada kedua kelompok tertera pada Tabel 3. Hasil analisis uji t tidak berpasangan menunjukkan tidak adanya perbedaan bermakna kadar feritin pada kelompok kasus dan kontrol. Kadar feritin dalam serum pada kelompok GPPH diperoleh hasil lebih tinggi dibandingkan anak sehat sebagai kelompok kontrol. Karena kadar feritin dalam serum tidak terdistribusi normal, digunakan nilai tengah (median).
Pada kelompok anak GPPH dilakukan pengisian kuesioner SPPAHI oleh orangtua siswa kelompok GPPH. Nilai tengah SPPAHI mendapatkan nilai 36 dengan kisaran 20-91. Berdasarkan hasil uji korelasi Spearman, tidak ada hubungan bermakna antara rerata kadar feritin dengan gejala klinis GPPH, koefisien korelasi $0,108(\mathrm{p}>0,05)$.

\section{Pembahasan}

Serum feritin adalah ukuran penanda penyimpanan besi di jaringan tubuh, termasuk otak. Kadar feritin yang rendah merupakan penanda awal kekurangan zat besi dan prekursor anemia defiensi besi. Feritin dianggap berkontribusi terhadap GPPH, selain pada gangguan kognitif dan belajar. ${ }^{6}$ Feritin diperlukan pada produksi tirosin hidroksilasi, enzim yang berperan dalam produksi levodopa, kemudian mengalami dekarboksilasi menjadi dopamin. Dopamin berkaitan dengan modulasi aktivitas psikomotor dan fungsi eksekutif sehingga diyakini berpengaruh terhadap GPPH. Dopamin bekerja 
dengan memprogamkan kembali fungsi otak melalui proses peningkatan rangsangan pada sinaps saat terjadi penguatan perilaku seseorang. ${ }^{5,7}$

Tidak diperoleh hubungan antara rerata kadar feritin dalam serum dengan gejala klinik GPPH. Median kadar feritin pada kelompok GPPH dan anak sehat adalah 38,7 dan $28 \mathrm{ng} / \mathrm{mL}$. Hal menarik pada penelitian ini adalah rerata kadar feritin yang lebih tinggi pada kelompok anak GPPH. Sementara itu, berbagai literatur menyatakan bahwa defisiensi feritin dijumpai pada GPPH. Jika digunakan cut off kadar feritin adalah 20 $\mathrm{ng} / \mathrm{mL}$ serum, diperoleh hasil 10 anak dengan defisiensi pada kelompok GPPH dan 9 anak pada kelompok anak sehat. Perbedaan kadar feritin tersebut mungkin disebabkan oleh perbedaan populasi penelitian, serta pola dan asupan makanan. Hasil penelitian ini serupa dengan studi yang dilakukan oleh The National Health and Nutrition Examination Survey (NHANES) Amerika Serikat-rerata kadar feritin pada kelompok anak GPPH dan kelompok kontrol masing-masing 39,7 $(17,2)$ dan $38,5 \mathrm{ng} / \mathrm{mL}(19,4)$, p-value $0,786 .^{8}$

Penelitian mengenai kadar feritin anak dengan GPPH pernah dilakukan di Jakarta, terhadap 33 anak usia 5-12 tahun, didapatkan rerata kadar feritin 51,31 (SD 27,7) ng/mL. Pada penelitian tersebut, tidak ada data disingkirkannya komorbiditas lain, diberikannya suplementasi besi serta tidak ada perbandingan dengan kelompok kontrol. Terdapat perbedaan hasil kuantifikasi gejala klinik yang diukur dengan perangkat Conners' Parent Rating Scale pada penelitian tersebut. Dengan perangkat kerja yang berbeda untuk menilai gejala klinis, peneliti memeroleh hasil yang berbeda. ${ }^{7}$

Berdasarkan jenis kelamin diperoleh anak laki-laki lebih banyak menjadi subjek penelitian dibandingkan perempuan (rasio 1,66:1). Rasio tersebut tidak jauh berbeda dengan berbagai studi epidemiologi mengenai GPPH yang menyebutkan kisaran anak laki-laki dibandingkan perempuan adalah 2-4 kali lipat lebih banyak. $^{9}$

Peneliti melakukan pemeriksaan laju endap darah pada subjek penelitian guna menyingkirkan kemungkinan inflamasi maupun infeksi kronik yang mungkin berpengaruh terhadap kadar feritin. Terdapat berbagai pendapat hubungan LED dengan kadar feritin. Penelitian yang dilakukan Oyenkunle (dalam Wiguna) ${ }^{10}$ menemukan bahwa terdapat predictive value pada serum feritin dihubungkan dengan LED, tetapi sebagian besar studi menyarankan pemeriksaan $C$-reactive protein untuk menyingkirkan infeksi.
Analisis selanjutnya adalah uji korelasi antara kadar feritin dengan gejala klinik GPPH yang dinilai menggunakan SPPAHI. Berdasarkan hasil korelasi Spearman tidak didapatkan korelasi kedua variabel tersebut. Hal tersebut serupa dengan penelitian sebelumnya mengenai hubungan kadar feritin dengan keparahan gejala GPPH yang menggunakan instrumen penilai. Penelitian yang dilakukan di Indonesia menyatakan bahwa tidak ada korelasi kadar feritin dengan nilai ACTRS maupun ACPRS. Demikian pula dengan penelitian yang dilakukan oleh Oner menyatakan bahwa tidak ada perbedaan kadar feritin pada instrumen CTRS. ${ }^{7,8,11}$

Kendala yang dialami selama pengambilan subjek penelitian adalah alokasi waktu yang kurang tepat karena bertepatan dengan musim ujian serta liburan, menyebabkan data yang dapat dijaring tidak lengkap. Selain itu, adanya darah yang lisis sehingga pengambilan darah perlu diulang kembali serta pengambilan sampel. Penulisan alamat yang kurang lengkap, persepsi orangtua mengenai penelitian ini juga memengaruhi populasi terjangkau. Demikian pula dengan cara pengisian kuesioner, yang secara mandiri, dapat terjadi ketidaksamaan persepsi orangtua terhadap butir pernyataan kuesioner.

Keterbatasan penelitian ini adalah banyak kuesioner yang tidak dikembalikan dan tidak sempat dilacak. Duapuluh lima persen calon subjek penelitian yang tidak terjangkau menyebabkan hasil penelitian ini tidak dapat disimpulkan secara umum. Data yang kurang, baik itu data demografi maupun kuesioner, membuat penelitian tidak mewakili populasi umum.

\section{Kesimpulan}

Serum feritin tidak terbukti berperan pada gejala klinis GPPH, terkait dengan aktivitas dopaminergik. Perbedaan rerata antara serum feritin tidak bermakna antara kelompok anak GPPH dibandingkan yang sehat. Penelitian ini masih dapat dilanjutkan dengan meneliti faktor lainnya, seperti peran feritin terhadap dopamin itu sendiri.

\section{Daftar pustaka}

1. Kaplan, Sadock, penyunting. Attention-deficit/ hyperactivity disorder. Comprehensive Textbook of Psychiatry. 
Edisi ke-9. Philladelphia: Lippincot, Williams \& Wilkins; 2009.h.3560-72.

2. Kementerian Kesehatan RI. Peraturan Menteri Kesehatan Republik Indonesia No. 330/ Menkes/PER II/ 2001 tentang Pedoman deteksi dini gangguan pemusatan perhatian dan hiperaktivitas pada anak serta penanganannya. Diakses 7 Juli 2014. Diunduh dari: http://www.rsstroke.com/files/peraturan/Setjen_Pusat/2011/ PMK_No._330_ttg_Pedoman_Deteksi_Dini_Gangguan_ Pemusatan_Perhatian_dan_Hiperaktivitas_Pada_Anak.pdf.

3. Syanborg P, Thernlund G, Gustafsson PA, Hägglöf B, Schacht A, Kadesjö B, dkk. Atomoxetine improves patient and family coping in attention deficit/ hyperactivity disorder: a randomized, double-blind, placebo-controlled study in Swedish children and adolescents. Eur Child Adolesc Psychiatry 2009;18:725-35.

4. Juneja M, Jain R, Singh V, Mallika V. Iron deficiency in indian children with attention deficit hyperactivity disorder. Indian Pediatr 2010;47:955-8.

5. Lahat E, Heyman E, Livne A, Goldman M, Bekovitch $\mathrm{M}$, Zachor D. Iron deficiency in children with attention deficit hyperactivity disorder. The Israel Med Assoc J 2011;13:530-3.

6. Millichap J.G, Yee MM, Davidson S. Serum ferritin in children with attention deficit hyperactivity disorder. Pediatr Neurol 2006;34:200-3.

7. Tumbelaka IA, Pusponegoro HD, Rohsiswanto R. Correlation between serum ferritin level and attention deficit/hyperactivity disorder symptom scores in children based on the abbreviated conners teachers rating scale. Pediatrica Indones 2012;52:329-35.

8. Kiddie JY, Weiss MD, Kitts D, Levy-Milne R, Wasdell MB. Nutritional study of children with attention deficit hyperactivity disorder: a pilot study. Int J Pediatr 2010: $1-7$

9. Frank-Briggs. Attention deficit hyperactivity disorder. J Pediatric Neurol 2011;9; 291-8

10. Wiguna T. Efek Medilfenidat kerja panjang $20 \mathrm{mg}$ terhadap perbaikan neuritransmitter dopaminergik dan gejala klinik pada anak dengan gangguan pemusatan perhatian dan/ hiperaktivitas, studi dengan menggunakan pencitraan magnestic resonance spectroscopy (desertasi). Jakarta: Program studi doktor fakultas kedokteran universitas Indonesia, 2009.

11. Oner P, Oner O, Relationship of ferritin to symptom ratings children with attention deficit hyperactivity disorder: effect of comorbidity. Child Psychiatry Hum Dev 2008;39:323-30. 